\title{
AN ASSESSMENT OF MOTIVES FOR OUTWARD FOREIGN DIRECT INVESTMENT OF CHINESE FIRMS: THE PERSPECTIVE OF THE ECLECTIC PARADIGM
}

\author{
Yulong Liu, Massey University, NZ
}

dx.doi.org/10.18374/JIBE-13-4.12

\begin{abstract}
This study aims to assess the outward foreign direct investment (OFDI) of Chinese firms and strategic motives from country specific characteristics. In literature, researches of FDI outflows have focused on the role of the stage of economic development of home countries and characteristics of host countries. However, FDI outflows from developing countries, especially from emerging countries like China, indicate that country-specific characteristics could have a unique influence on driving OFDI regardless of the stage of economic development. Thus, there is a pertinent need to study the impact of a home country's specific characteristics on its OFDI. This paper attempts to fill a research gap by focusing on the country-specific factors for Chinese MNEs to engage in so much FDI and address to what extent, these factors from macro-environment influence its firms' propensity to invest abroad. Relevant hypotheses are theoretically developed and empirically tested by using the eclectic paradigm covering the specific period of OFDI by Chinese MNEs.
\end{abstract}

Keywords: Outward foreign direct investment (OFDI), motives, China 